\title{
MOTIVASI DAN DISIPLIN KERJA SERTA PENGARUHNYA TERHADAP KINERJA GURU
}

\author{
Sholehah \\ Pengawas Sekolah Menengah Pertama, Indramayu, sholehaeha@gmail.com
}

Received April 12, 2018, reviewed July 3, 2018, published September 30, 2018

Citation: Sholehah. (2018). Motivasi dan Disiplin kerja Serta Pengaruhnya terhadap Kinerja Guru. Edum

Journal, Vol 1, No 2, 96-108, September 2018

DOI: https://doi.org/10.31943/edumjournal.v1i2.481

\begin{abstract}
ABSTRAK
Perhatian utama penelitian ini adalah untuk mengetahui dan menganalisis pengaruh motivasi kerja dan disiplin kerja terhadap kinerja guru. Penelitian ini mengggunak metode survey dengan studi deskriptif terhadap 35 orang guru sebagai responden. Teknik pengumpulan data menggunakan angket ysng sudah melalui uji validitas dan reliabilitas, dilengkapi dengan observasi dan wawancara kepada pihak terkait. Teknik analisis data menggunakan analisis regresi baik parsial maupun ganda. Hasil penelitian menunjukkan bahwa: (1) Terdapat pengaruh yang positif dan signifikan motivasi kerja terhadap kinerja guru. (2) Terdapat pengaruh yang positif dan signifikan disiplin kerja terhadap kinerja guru. (3) Terdapat pengaruh yang positif dan signifikan motivasi dan disiplin kerja guru secara bersama-sama terhadap kinerja guru. Maknanya semakin tinggi disiplin dan motivasi kerja guru maka semakin tinggi pula kinerja guru. Bertolak dari kondisi tersebut, penulis menyarankan, bahwa: (1) Agar selalu dapat mengikuti perkembangan yang terjadi, maka kepada guru hendaknya tetap semangat untuk menambah dan memperbaharui ilmu pengetahuan. Memberikan keteladanan kepada peserta didik, baik dalam semangat belajar maupun menegakkan disiplin. Setelah motivasi dan disiplin menjadi bagian dari keseharian guru, besar harapan kinerjanya meningkat sehingga mendorong terwujudnya lembaga pendidikan yang bermutu. (2) Kepala sekolah hendaknya lebih memperhatikan pemberian penghargaan terhadap guru yang berprestasi, serta secara berkesinambungan memberikan pembinaan berkaitan dengan pemeliharaan semangat bekerja dan keteladanan dalam mengikuti peraturan sekolah.
\end{abstract}

\section{Kata Kunci: Motivasi Kerja, Disiplin Kerja dan Kinerja Guru}

\begin{abstract}
Therefore, the main concern of this research is to find out and analyze the influence of work motivation and work discipline on teacher performance. This research was conducted through survey methods with descriptive studies of 35 teachers as respondents. Data collection techniques using questionnaires that have been tested through validity and reliability, complemented by observations and interviews with related parties. The data analysis technique uses both partial and multiple regression analysis. The results of the study show that: (1) There is a positive and significant effect of work motivation on teacher performance. (2) There is a positive and significant influence on work discipline on teacher performance. (3) There is a positive and significant effect of teacher work motivation and discipline together on teacher performance. The meaning is the higher the discipline and motivation of the teacher's work, the higher the teacher's performance. Starting from these conditions, the authors suggest, that: (1) In order to always be able to keep up with the developments that occur, then the teacher should keep the spirit to add and renew science. Providing exemplary to students, both in the spirit of learning and enforcing discipline. After motivation and discipline become part of the teacher's daily life, it is hoped that their performance will increase so as to encourage the realization of quality educational institutions. (2) Principals
\end{abstract}


should pay more attention to awarding teachers who excel, and continuously provide guidance related to maintaining the spirit of work and exemplary in following school rules.

Keywords: Work Motivation, Work Discipline and Teacher Performance

\section{PENDAHULUAN}

Guru sebagai ujung tombak perubahan dalam memiliki peranan yang penting dalam meningkatkan kualitas pendidikan. Kualitas pendidikan terutama kualitas proses belajar mengajar sangat ditentukan oleh kualitas guru. Oleh karena itu, seorang guru harus memiliki kinerja yang unggul. Menurut Drucker (2007:242), kinerja guru memiliki empat dimensi, yakni: (1) Dimensi fisiologis; (2) Dimensi psikologis; (3) Dimensi; (4) Dimensi keseimbangan.

Kinerja guru dapat dilihat saat melaksanakan interaksi belajar mengajar di kelas (Inah, 2015). Kinerja guru dapat dirurnuskan sebagai unjuk kerja yang ingin dicapai, berupa prestasi (kualitas individu) yang diperlihatkan (tampilan atau unjuk kerja) dibidang yang menjadi tanggung jawabnya (tugas fungsional) dalam bentuk kemampuan kerja berupa: (a) pengetahuan dan penguasaan materi pembelajaran yang akan diajarkan kepada peserta didik, (b) keterampilan perilaku yang berkaitan dengan pengusaan didaktis metodologis yang bersifat pedagogis maupun andragogis, (c) keterampilan untuk melakukan hubungan baik dengan unsur manusia yang terlibat dalam proses pendidikan guna melaksanakan kewajiban atau tugas pekerjaan yang menjadi wewenang dan tanggung jawabnya pada waktu tertentu berdasarkan prosedur dan aturan yang berlaku untuk kepentingan pencapaian tujuan yang telah ditetapkan (Hafid, 2017).

Banyak faktor yang mempengaruhi Kinerja Guru, salah satunya terkait dengan motivasi dan disiplin guru dalam mengajar. Disiplin adalah suatu keadaan tertib, ketika orang-orang yang tergabung dalam suatu sistem tunduk pada peraturan-peraturan yang ada dengan senang hati (Mulyasa, 2009: 191). Disiplin mempunyai peran sangat penting dalam mengarahkan kehidupan manusia untuk meraih citacitanya serta kesuksesannya dalam bekerja, karena tanpa adanya kedisiplinan maka seseorang tidak mempunyai patokan tentang apa yang baik dan yang buruk dalam tingkah lakunya (Nugraheni \& Rahmayanti, 2016). 
Berdasarkan hasil penelitian relevan seperti $\mathrm{ada}$

(1) Nugraheni \& Rahmayanti (2016) menyimpulkan bahwa disipin kerja sangat berpengaruh positif dan signifikan terhadap kinerja guru di MI Al Islam Tempel dan MI Al Ihsan Medari. (2) Nikmatul Husna (2017) menyimpulkan bahwa disiplin kerja berpengaruh positif dan signifikan terhadap kinerja guru pada SMAN 1 Canduang Kabupaten Agam.

Hal lain terkait dengan motivasi guru dalam mengajar, motivasi kerja guru merupakan faktor yang dapat mempengaruhi kinerja guru sebab motivasi kerja sebagai rangsangan yang membangkitkan gairah guru dalam bekerja (Ruliaty, 2009). Motivasi akan mengarah ke hal yang positif jika berefek pada kepuasan pada diri guru dan sebaliknya, jika mengarah ke hal yang negatif maka akan berefek pada ketidak puasan (Choiriyah, dkk, 2017). Guru tanpa kepuasan kerja tidak dapat diharapkan akan memiliki komitmen tinggi pada organisasi. Ada kecenderungan guru menghindar dari pekerjaannya, seperti tidak melibatkan diri dalam bekerja, tidak antusias dalam mengajar, menolak kebijakan dan nilai-nilai organisasi. bahkan bisa terjadi guru beralih ke pekerjaan lain atau organisasi lain jika
(Choiriyah, dkk, 2017).

Berdasarkan hal tersebut maka peneliti tertarik untuk melaporkan hasil riset tentang motivasi dan disiplin kerja serta pengaruhnya terhadap kinerja guru.

\section{METODE PENELITIAN}

Penelitian ini dilaksanakan pada guru SD Negeri di Kecamatan Arahan Kabupaten Indramayu. Pendekatan yang digunakan adalah pendekatan kuantitatif dengan jenis metode analisis statistik deskriptif. Jenis penelitian ini merupakan penelitian yang dirancang untuk mendapatkan informasi tentang korelasi antara variabel dalam populasi. Motivasi kerja $\left(\mathrm{X}_{1}\right)$ dan disiplin kerja $\left(\mathrm{X}_{2}\right)$ sebagai variabel bebas. Sedangkan kinerja guru sebagai variabel terikat (Y). Dalam penelitian ini digambarkan kontribusi motivasi kerja terhadap kinerja guru, disiplin kerja terhadap kinerja guru, serta motivasi kerja dan disiplin kerja secara bersama-sama terhadap kinerja guru.

Teknik pengumpulan data menggunakan angket kepada 35 orang responden yang merupakan simple random sampling dari total populasi 130 orang. Responden ditentukan sebanyak 35 orang 
$(26 \%)$ dari populasi mengacu pada dianalisis, selanjutnya untuk mengetahui pendapat Arikunto (2007:116). Angket signifikansi dan keterpengaruhan dihitung yang disebarkan telah melalui uji validitas dengan regresi linear dan ganda dan reliabilitas. Setelah terkumpul data menggunakan SPSS versi 22.

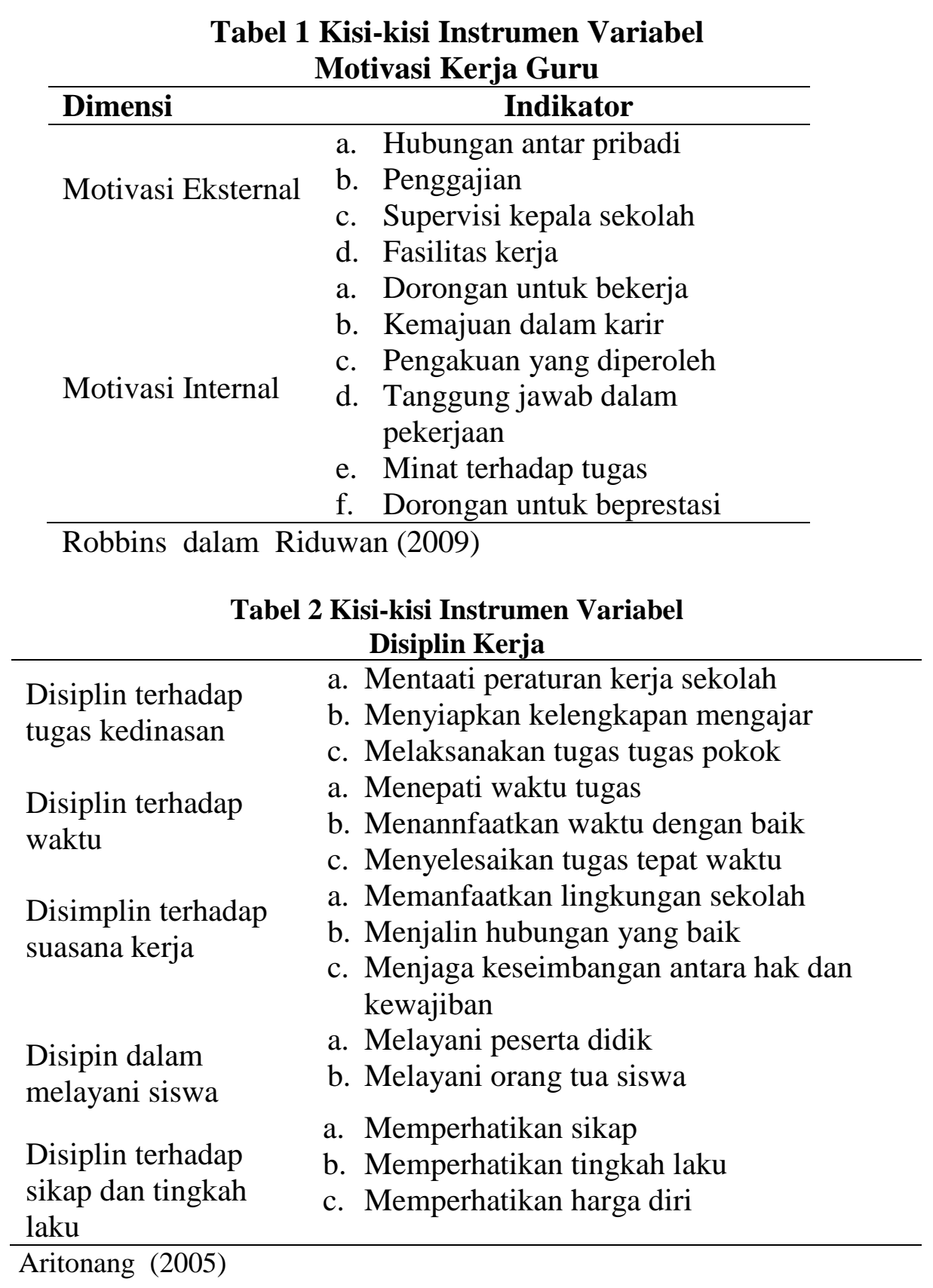


Tabel 3: Kisi-kisi Instrumen Variabel Kinerja Guru

\begin{tabular}{ll}
\hline Rasional & a. Sesuai alokasi waktu \\
Konsisten & b. Penilaian sesuai kemampuan \\
Tepat dan Jelas & a. Dedikasi \\
& b. Meteri sesuai kurikulum \\
Efisien & b. Mementingkan tujuan organisasi \\
& a. Penggunaan sumber daya secara \\
& b. Hemat \\
Terarah & a. Adanya tujuan pembelajaran \\
Tertantang & b. Adanya evaluasi \\
Sistematis & a. Mempelajari hal baru \\
& b. Melakukan tugas sulit \\
Mencapai target & a. Menyusun program satuan \\
& b. Membuat rencana pelajaran \\
Disepakati & a. Pekerjaan baik \\
Terkait dengan & a. Merusaha mencapai target \\
waktu & b. Mengikuti prosedur dan peraturan \\
Disiplin & a. Materi selesai disampaikan \\
& b. Pekerjaan selesai tepat waktu \\
\hline
\end{tabular}

Kusnadi (2003)

HASIL PENELITIAN DAN individual (parsial) terhadap kinerja guru

PEMBAHASAN

\section{Pengaruh Motivasi Kerja Terhadap Kinerja Guru}

Untuk mengetahui besaran pengaruh motivasi kerja guru $\left(\mathrm{X}_{1}\right)$ secara
(Y) dapat dilihat dari nilai t pada tabel Coefficients dibawah ini dengan kriteria pengujian jika tingkat signifikansi lebih kecil dari 0,05 .

Tabel 4 Uji (t) Variabel $X_{1}$ terhadap $Y$ Coefficients $^{\mathrm{a}}$

\begin{tabular}{|c|c|c|c|c|c|}
\hline \multirow[b]{2}{*}{ Model } & \multicolumn{2}{|c|}{$\begin{array}{l}\text { Unstandardized } \\
\text { Coefficients }\end{array}$} & \multirow{2}{*}{$\begin{array}{c}\begin{array}{c}\text { Standardized } \\
\text { Coefficients }\end{array} \\
\text { Beta }\end{array}$} & \multirow[b]{2}{*}{$\mathrm{t}$} & \multirow[b]{2}{*}{ Sig. } \\
\hline & B & Std. Error & & & \\
\hline 1 (Constant) & 64,144 & 16,577 & & 3,870 &, 000 \\
\hline Motivasi_Kerja_X & ,345 & , 168 & 337 & 2,055 & ,048 \\
\hline
\end{tabular}

a. Dependent Variable: Kinerja_Guru_Y 
Berdasarkan tabel hasil uji t diperoleh

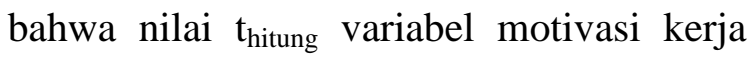
guru $\left(\mathrm{X}_{1}\right)$ memiliki nilai sebesar $p$-value $0,000<0,05$ artinya berdistribusi signifikan. Hal tersebut berarti motivasi kerja guru $\left(\mathrm{X}_{1}\right)$ secara parsial berpengaruh terhadap kinerja guru (Y). Persamaan regresi $\widehat{y}=\mathrm{a}+\mathrm{bx}_{1}$ dari hasil perhitungan diperoleh $\hat{y}=$ $64,144+0,345 \mathrm{X}_{1}$. Konstanta sebesar 64,144 menyatakan bahwa jika ada kenaikan nilai dari variabel motivasi kerja guru $\left(\mathrm{X}_{1}\right)$, maka kinerja guru $(\mathrm{Y})$ adalah 64,144. Koefesien regresi sebesar 0,345 menyatakan bahwa setiap perubahan satu skor atau nilai motivasi kerja guru akan memberikan skor 0,345. Dari pengambilan keputusan yaitu dengan membandingkan $\mathrm{F}$ hitung dengan nilai $\mathrm{F}$ tabel sebagai berikut: jika nilai signifikansi $<0,05$, maka Ho ditolak artinya koefesien regresi signifikan, dan sebaliknya.

Tabel 5 Signifikansi Pengaruh Variabel $X_{1}$ terhadap $Y$

\begin{tabular}{|c|c|c|c|c|c|c|}
\hline \multicolumn{7}{|c|}{ ANOVA $^{a}$} \\
\hline$\overline{\mathrm{Moc}}$ & & Sum of Squares & $\mathrm{df}$ & Mean Square & $\mathrm{F}$ & Sig. \\
\hline & Regression & 141,570 & 1 & 141,570 & 4,221 &, $048^{\mathrm{b}}$ \\
\hline & Residual & 1106,716 & 33 & 33,537 & & \\
\hline & Total & 1248.286 & 34 & & & \\
\hline
\end{tabular}

a. Dependent Variable: Kinerja_Guru_Y

b. Predictors: (Constant), Motivasi_Kerja_X $X_{1}$

Berdasarkan tabel hasil uji anova signifikan. Selanjutnya untuk mengetahui atau $F_{\text {test }}$ sebesar 4,221 dan nilai seberapa besar pengaruh motivasi kerja signifikansi $0,048<0,05$. Dengan demikian guru terhadap kinerja guru dapat dilihat $\mathrm{H}_{\mathrm{o}}$ ditolak artinya pengaruh motivasi kerja dari hasil perhitungan koefesien determinasi guru terhadap kinerja guru adalah pada tabel dibawah ini:

Tabel 6 Besaran Pengaruh Variabel $X_{1}$ Terhadap $Y$ Model Summary

\begin{tabular}{|c|c|r|r|r|}
\hline Model & $\mathrm{R}$ & R Square & Adjusted R Square & Std. Error of the Estimate \\
\hline 1 &, $337^{\mathrm{a}}$ &, 113 &, 087 & 5,791 \\
\hline
\end{tabular}

a. Predictors: (Constant), Motivasi_Kerja_ $\mathrm{X}_{1}$

Dari tabel di atas terlihat bahwa $R$ variabel motivasi kerja guru, sedangkan Square sebesar 0,113 , hal ini berarti bahwa sisanya 88,7\% dipengaruhi oleh faktor lain $11,3 \%$ kinerja guru dipengaruhi oleh yang tidak diteliti. 
Pengaruh Disiplin Kerja Guru Terhadap (parsial) terhadap kinerja guru (Y) dapat Kinerja Guru dilihat dari nilai t pada tabel Coefficients Untuk mengetahui besaran pengaruh dibawah ini dengan kriteria pengujian jika disiplin kerja guru $\left(\mathrm{X}_{2}\right)$ secara individual tingkat signifikansi lebih kecil dari 0,05.

Tabel 7 Uji ( $t$ ) Variabel $X_{2}$ terhadap $Y$ Coefficients $^{\mathrm{a}}$

\begin{tabular}{|c|c|c|c|c|c|}
\hline \multirow[b]{2}{*}{ Model } & \multicolumn{2}{|c|}{$\begin{array}{l}\text { Unstandardized } \\
\text { Coefficients }\end{array}$} & \multirow{2}{*}{$\begin{array}{c}\begin{array}{c}\text { Standardized } \\
\text { Coefficients }\end{array} \\
\text { Beta }\end{array}$} & \multirow[b]{2}{*}{$t$} & \multirow[b]{2}{*}{ Sig. } \\
\hline & $\mathrm{B}$ & Std. Error & & & \\
\hline $1 \quad$ (Constant $)$ & 107,765 & 7,377 & & 14,608 & 000 \\
\hline Disiplin_Kerja_ $X_{2}$ & ,092 & ,070 &,- 223 & $-1,317$ & , 197 \\
\hline
\end{tabular}

a. Dependent Variable: Kinerja_Guru_Y

Berdasarkan tabel hasil uji t diperoleh dari variabel disiplin kerja guru $\left(\mathrm{X}_{2}\right)$, bahwa nilai $t_{\text {hitung }}$ variabel disiplin kerja kinerja guru (Y) adalah 107,765. Koefesien guru $\left(\mathrm{X}_{2}\right)$ memiliki nilai sebesar p-value regresi sebesar 0,992 menyatakan bahwa $0,000<0,05$ artinya signifikan. Dengan setiap perubahan satu skor atau disiplin demikian disiplin kerja guru $\left(\mathrm{X}_{2}\right)$ secara kerja guru akan memberikan skor 0,992. parsial berpengaruh terhadap kinerja guru Dari pengambilan keputusan yaitu dengan (Y). Persamaan regresi $\hat{y}=\mathrm{a}+\mathrm{bx}_{2}$ dari membandingkan $\mathrm{F}$ hitung dengan nilai $\mathrm{F}$ hasil perhitungan diperoleh $\hat{y}=107,765+$ tabel sebagai berikut: jika nilai signifikansi $0,992 X_{2}$. Konstanta sebesar $107,765<0,05$, maka Ho ditolak artinya koefesien menyatakan bahwa jika ada kenaikan nilai regresi signifikan, dan sebaliknya.

Tabel 8 Signifikansi Pengaruh Variabel $\mathrm{X}_{2}$ terhadap $\mathrm{Y}$ ANOVA $^{\mathrm{a}}$

\begin{tabular}{|c|c|c|c|c|c|}
\hline Model & $\begin{array}{l}\text { Sum of } \\
\text { Squares }\end{array}$ & df & $\begin{array}{c}\text { Mean } \\
\text { Square }\end{array}$ & $\mathrm{F}$ & Sig. \\
\hline 1 Regression & 62,317 & 1 & 62,317 & 1,734 &, $007^{\mathrm{b}}$ \\
\hline Residual & 1185,968 & 33 & 35,938 & & \\
\hline Total & 1248,286 & 34 & & & \\
\hline
\end{tabular}

a. Dependent Variable: Kinerja_Guru_Y

b. Predictors: (Constant), Disiplin_Kerja_X $X_{2}$

Berdasarkan tabel hasil uji anova pengaruh disiplin kerja guru terhadap atau $\mathrm{F}$ test sebesar 1,734 dan signifikansi kinerja guru adalah signifikan. Selanjutnya $0,007<0,05$ sehingga $\mathrm{H}_{\mathrm{o}}$ ditolak artinya untuk mengetahui seberapa besar pengaruh 
disiplin kerja guru terhadap kinerja guru koefesien determinasi pada tabel dibawah dapat dilihat dari hasil perhitungan ini:

Tabel 9 Besaran Pengaruh Variabel $X_{2}$ terhadap $Y$ Model Summary

\begin{tabular}{|c|r|r|r|r|}
\hline Model & $\mathrm{R}$ & R Square & $\begin{array}{c}\text { Adjusted R } \\
\text { Square }\end{array}$ & $\begin{array}{c}\text { Std. Error of the } \\
\text { Estimate }\end{array}$ \\
\hline 1 &, $223^{\mathrm{a}}$ &, 050 &, 021 & 5,995 \\
\hline
\end{tabular}

a. Predictors: (Constant), Disiplin_Kerja_X 2

Dari tabel di atas terlihat bahwa $R$

Square sebesar 0,050, hal ini berarti bahwa

$5 \%$ kinerja guru dipengaruhi oleh variabel

disiplin kerja guru, sedangkan sisanya $95 \%$

dipengaruhi oleh faktor lain yang tidak diteliti.

Pengaruh Motivasi dan Disiplin lebih kecil dari 0,05 .

\section{Terhadap Kinerja Guru}

Tabel 10 Uji (t) Variabel $X_{1}$ dan $X_{2}$ terhadap $Y$

Coefficients $^{\mathrm{a}}$

\begin{tabular}{|c|c|c|c|c|c|c|}
\hline \multirow{2}{*}{\multicolumn{2}{|c|}{ Model }} & \multicolumn{2}{|c|}{$\begin{array}{c}\text { Unstandardized } \\
\text { Coefficients }\end{array}$} & \multirow{2}{*}{$\begin{array}{l}\text { Standardized } \\
\text { Coefficients } \\
\text { Beta }\end{array}$} & \multirow[b]{2}{*}{$t$} & \multirow[b]{2}{*}{ Sig. } \\
\hline & & $\mathrm{B}$ & Std. Error & & & \\
\hline & (Constant) & 73,649 & 17,663 & & 4,170 & ,000 \\
\hline & Motivasi_Kerja_X ${ }_{1}$ & ,349 &, 166 &, 340 & 2,105 &, 043 \\
\hline & Disiplin_Kerja_X $X_{2}$ & ,094 &, 066 &,- 228 & $-1,413$ & , 167 \\
\hline
\end{tabular}

a. Dependent Variable: Kinerja_Guru_Y

Berdasarkan tabel hasil uji $\mathrm{t}$ Untuk mengetahui persamaan regresi dapat diperoleh bahwa nilai $t_{\text {hitung }}$ variabel dilihat dari tabel di atas. Berdasarkan tabel motivasi kerja guru $\left(\mathrm{X}_{1}\right)$ dan disiplin kerja tersebut menunjukkan persamaan regresi guru $\left(\mathrm{X}_{2}\right)$ secara bersama-sama (simultan) linier ganda: $\widehat{\mathrm{Y}}=73,649+0,349 \mathrm{X} 1+$ memiliki nilai sebesar $p$-value $0,000<0,05 \quad 0,094 \mathrm{X} 2$. Persamaan tersebut menyatakan artinya signifikan. Dengan demikian bahwa setiap penambahan $X_{1}$ dan $X_{2}$ motivasi kerja guru $\left(\mathrm{X}_{1}\right)$ dan disiplin kerja sebesar 1 maka akan meningkatkan $\mathrm{Y}$ guru $\left(\mathrm{X}_{2}\right)$ secara bersama-sama (simultan) sebesar 0,349 dan 0,094, artinya setiap berpengaruh terhadap kinerja guru $(\mathrm{Y})$. peningkatan motivasi kerja guru dan 
disiplin kerja guru sebesar 1, akan nilai $\mathrm{F}$ tabel sebagai berikut: Jika nilai meningkatkan kinerja guru sebesar 0,349 signifikansi < 0,05, maka Ho ditolak artinya dan 0,094 . koefisien regresi signifikan, dan sebaliknya.

Dari pengambilan keputusan yaitu dengan membandingkan $\mathrm{F}$ hitung dengan

Tabel 11Signifikansi Pengaruh Variabel $X_{1}$ dan $X_{2}$ terhadap $Y$ ANOVA $^{\mathrm{a}}$

\begin{tabular}{|c|c|c|c|c|c|c|}
\hline Model & & $\begin{array}{c}\text { Sum of } \\
\text { Squares }\end{array}$ & df & $\begin{array}{c}\text { Mean } \\
\text { Square }\end{array}$ & $\mathrm{F}$ & Sig. \\
\hline \multirow[t]{3}{*}{1} & Regression & 206,551 & 2 & 103,275 & 3,172 &, $015^{\mathrm{b}}$ \\
\hline & Residual & 1041,735 & 32 & 32,554 & & \\
\hline & Total & 1248,286 & 34 & & & \\
\hline
\end{tabular}

a. Dependent Variable: Kinerja_Guru_Y

b. Predictors: (Constant), Disiplin_Kerja_X $X_{2}$, Motivasi_Kerja_X $X_{1}$

Berdasarkan tabel hasil uji anova mengetahui besaran pengaruh motivasi atau $F_{\text {test }}$ sebesar 3,172 dan signifikansi kerja guru dan disiplin kerja guru secara $0,015<0,05$ sehingga $\mathrm{H}_{\mathrm{o}}$ ditolak artinya simultan terhadap kinerja guru dapat pengaruh motivasi kerja guru dan disiplin dilihat dari hasil perhitungan koefesien kerja guru secara simultan terhadap kinerja determinasi pada tabel dibawah ini: guru adalah signifikan. Selanjutnya untuk

Tabel 12 Besaran Pengaruh Variabel $X_{1}$ dan $X_{2}$ Terhadap $Y$

\begin{tabular}{|c|r|r|r|r|}
\hline Model & R & R Square & $\begin{array}{c}\text { Adjusted R } \\
\text { Square }\end{array}$ & $\begin{array}{c}\text { Std. Error of } \\
\text { the Estimate }\end{array}$ \\
\hline 1 &, $407^{\mathrm{a}}$ &, 165 &, 113 & 5,706 \\
\hline
\end{tabular}

a. Predictors: (Constant), Disiplin_Kerja_X $X_{2}$, Motivasi_Kerja_X 
Dari tabel di atas terlihat bahwa $R$ Square sebesar 0,165, hal ini berarti bahwa 16,5 \% kinerja guru dipengaruhi oleh variabel motivasi kerja guru dan disiplin kerja guru secara simultan, sedangkan sisanya 83,5 \% dipengaruhi faktor lain yang tidak diteliti.

\section{Pembahasan}

Permasalahan yang ingin dijawab dalam penelitian ini adalah adakah pengaruh motivasi kerja guru terhadap kinerja guru. Secara empirik, hasil penelitian ini menginformasikan: (1) Terdapat pengaruh positif dan signifikan antara motivasi kerja guru terhadap kinerja guru, serta (2) besarnya kontribusi motivasi kerja guru terhadap kinerja guru ditunjukkan oleh hasil penelitian bahwa motivasi kerja guru yang terdiri dari dimensi: (1) Motivasi internal/intrinsik; (2) Motivasi eksternal/ekstrinsik (Robbins dalam Riduwan, 2009:145), membawa implikasi yang signifikan terhadap kinerja guru dengan dimensi: (1) Rasional; (2) Konsisten; (3) Tepat dan jelas; (4) Efisien; (5) Terarah; (6) Tertantang; (7) Sistematis; (8) Mencapai target; (9) Disepakati; (10) Terkait dengan waktu; (11) Disiplin (Kusnadi, 2003:268). Menurut Mulyasa (2005:112) "Motivasi adalah tenaga pendorong atau penarik yang menyebabkan adanya tingkah laku ke arah suatu tujuan tertentu.
Sejalan dengan pendapat Mulyasa (2006:71) mengemukakan bahwa "Disiplin kerja guru adalah suatu proses yang dilakukan untuk menggerakan guru agar perilaku mereka dapat diarahkan pada upaya-upaya yang nyata untuk mencapai tujuan yang telah ditetapkan". Namun demikian kinerja guru ini tidak hanya dipengaruhi oleh motivasi kerja guru saja, ada faktor lain (epsilon), selain dari disiplin kerja guru, yang juga berpengaruh, yang tidak dikaji dalam penelitian ini. Dengan demikian, hasil penelitian ini mengindikasikan bahwa semakin bagus motivasi kerja guru, maka akan diikuti oleh semakin tingginya kinerja guru. Hal ini dapat diterangkan oleh persamaan regresi $\hat{y}=64,144+$ $0,345 X_{1}$. Dengan persamaan regresi tersebut dapat diinterpretasikan bahwa jika motivasi kerja guru $\left(\mathrm{X}_{1}\right)$ dengan kinerja guru $(\mathrm{Y})$ diukur dengan instrumen yang dikembangkan dalam penelitian ini, maka setiap perubahan skor motivasi kerja guru sebesar satu satuan dapat diestimasikan skor kinerja guru akan berubah 0,345 satuan pada arah yang sama.

Berdasarkan temuan empirik yang menunjukkan adanya pengaruh yang signifikan motivasi kerja guru terhadap kinerja guru, maka hasil penelitian ini memberikan beberapa informasi, di 
antaranya: (1) Motivasi kerja guru memberikan kontribusi yang berarti terhadap kinerja guru, (2) Salah satu cara untuk meningkatkan kinerja guru adalah dengan meningkatkan motivasi kerja guru, serta (3) Persentase kontribusi motivasi kerja guru terhadap kinerja guru adalah sebesar $11,3 \%$, sementara sisanya dipengaruhi oleh variabel lain, selain variabel disiplin kerja guru, yang tidak dikaji dalam penelitian ini (epsilon).

Selanjutnya, permasalahan yang ingin dijawab dalam penelitian ini adalah adakah pengaruh disiplin kerja guru terhadap kinerja guru. Secara empirik, hasil penelitian ini menginformasikan: (1) Terdapat pengaruh positif dan signifikan antara disiplin kerja guru terhadap kinerja guru, serta (2) besarnya kontribusi disiplin kerja guru terhadap kinerja guru ditunjukkan oleh hasil penelitian bahwa disiplin kerja guru yang terdiri dari dimensi: (1) Disiplin terhadap tugas kedinasan; (2) Disiplin terhadap waktu; (3) Disiplin terhadap suasana kerja; (4) Disiplin di dalam melayani siswa dan orang tua siswa; (5) Disiplin terhadap sikap dan tingkah laku (Aritonang, 2005), membawa implikasi yang signifikan terhadap kinerja guru dengan dimensi: (1) Rasional; Konsisten; (3) Tepat dan jelas; (4)
Efisien; (5) Terarah; (6) Tertantang; (7)

Sistematis; (8) Mencapai target; (9)

Disepakati; (10) Terkait dengan waktu;

(11) Disiplin (Kusnadi, 2003:268).

Menurut Sinambela (2012) dalam Barnawi \& Arifin (2012:110) mengatakan bahwa 'disiplin pada hakekatnya adalah kepatuhan pada aturan atau perintah yang ditetapkan oleh organisasi'. Disiplin merupakan tindakan manajemen untuk mendorong agar para anggota organisasi dapat memenuhi berbagai ketentuan dan peraturan yang berlaku dalam suatu organisasi'. Namun demikian kinerja guru ini tidak hanya dipengaruhi oleh disiplin kerja guru saja, ada faktor lain (epsilon), selain dari motivasi kerja guru, yang juga berpengaruh, yang tidak dikaji dalam penelitian ini. Dengan demikian, hasil penelitian ini mengindikasikan bahwa semakin baik disiplin kerja guru, maka akan diikuti oleh semakin tingginya kinerja guru. Hal ini dapat diterangkan oleh persamaan regresi $\mathrm{y}=107,765+$ $0,992 X_{2}$. Dengan persamaan regresi tersebut dapat diinterpretasikan bahwa jika disiplin kerja guru $\left(\mathrm{X}_{2}\right)$ dengan kinerja guru $(\mathrm{Y})$ diukur dengan instrumen yang dikembangkan dalam penelitian ini, maka setiap perubahan skor kinerja guru sebesar satu satuan dapat diestimasikan 
skor kinerja guru akan berubah 0,992 satuan pada arah yang sama.

Berdasarkan temuan empirik yang menunjukkan adanya pengaruh yang signifikan disiplin kerja guru terhadap kinerja guru, maka hasil penelitian ini memberikan beberapa informasi, di antaranya: (1) Disiplin kerja guru memberikan kontribusi yang berarti terhadap kinerja guru; (2) Salah satu cara untuk meningkatkan kinerja guru adalah dengan meningkatkan disiplin kerja guru, serta (3) Persentase kontribusi disiplin kerja guru terhadap kinerja guru adalah sebesar 16,5 \%, sementara sisanya dipengaruhi oleh variabel lain, selain variabel motivasi kerja guru, yang tidak dikaji dalam penelitian ini (epsilon).

Terakhir, permasalahan yang ingin dijawab dalam penelitian ini adalah adakah pengaruh motivasi kerja guru, dan disiplin kerja guru secara bersamasama terhadap kinerja guru. Secara empirik, hasil penelitian ini menginformasikan,. bahwa terdapat pengaruh positif dan signifikan antara motivasi kerja guru dan disiplin kerja guru secara bersama-sama terhadap kinerja guru. Sutermeister (2000:45) berpendapat bahwa" ...we have recognized that empoyee performance depends on both ability and motivation". Selanjutnya diungkapkan bahwa: "Ability is deemed to result from knowledge and skill. Knowledge in turn is affected by education, experience, training and interest. Skill is affected by attitude and personality as well as by education, experience, training and interacting forces in physical condition of the joy and individual need." Dengan kata lain "performance" atau kinerja ditentukan oleh (1) kemampuan yang diperoleh dari hasil pendidikan, pelatihan, pengalaman, dan (2) motivasi, yang merupakan perhatian khusus dari hasrat seorang pegawai dalam melaksankan suatu pekerjaan dengan baik. Namun demikian kinerja guru ini tidak hanya dipengaruhi oleh motivasi kerja guru, dan disiplin kerja guru saja, ada faktor lain (epsilon), yang juga berpengaruh, yang tidak dikaji dalam penelitian ini. Dengan demikian, hasil penelitian ini mengindikasikan bahwa semakin baik motivasi kerja guru, dan semakin tinggi disiplin kerja guru, maka akan diikuti oleh semakin tingginya kinerja guru. Hal ini dapat diterangkan oleh persamaan regresi: $\widehat{Y}=73,649+$ $0,349 \mathrm{X} 1+0,094 \mathrm{X} 2$.

Dengan persamaan regresi tersebut dapat diinterpretasikan bahwa jika motivasi kerja guru $\left(\mathrm{X}_{1}\right)$, dan disiplin kerja guru $\left(\mathrm{X}_{2}\right)$ dengan kinerja guru $(\mathrm{Y})$ diukur dengan instrumen yang dikembangkan dalam penelitian ini, maka 
setiap perubahan skor motivasi kerja guru dan disiplin kerja guru sebesar satu satuan dapat diestimasikan skor kinerja guru akan berubah 0,349 dan 0,094 satuan pada arah yang sama.

Berdasarkan temuan empirik yang menunjukkan adanya pengaruh yang signifikan motivasi kerja guru, dan disiplin kerja guru terhadap kinerja guru, maka hasil penelitian ini memberikan beberapa informasi, di antaranya: (1) Motivasi kerja guru, dan disiplin kerja guru memberikan kontribusi yang berarti terhadap kinerja guru; (2) Salah satu cara untuk meningkatkan kinerja guru adalah dengan meningkatkan motivasi kerja guru dan disiplin kerja guru; (3) Persentase kontribusi yang diberikan oleh motivasi kerja guru dan disiplin kerja guru secara bersama-sama terhadap kinerja guru adalah sebesar $5 \%$, sementara sisanya dipengaruhi faktor lain yang tidak dibahas dalam penelitian ini (epsilon).

\section{KESIMPULAN}

Berdasarkan hasil penelitian, dan pembahasan yang telah dilakukan maka dapat ditarik kesimpulan sebagai berikut: (1) Terdapat pengaruh yang positif dan signifikan motivasi kerja terhadap kinerja guru. Maknanya semakin tinggi motivasi kerja guru maka semakin tinggi pula kinerja guru. (2) Terdapat pengaruh yang positif dan signifikan disiplin kerja terhadap kinerja guru. Maknanya semakin tinggi disiplin kerja guru maka semakin tinggi pula kinerja guru. (3) Terdapat pengaruh yang positif dan signifikan motivasi dan disiplin kerja guru secara bersama-sama terhadap kinerja guru. Maknanya semakin tinggi disiplin dan motivasi kerja guru maka semakin tinggi pula kinerja guru.

\section{DAFTAR PUSTAKA}

Aritonang, K.T. (2005). Kompensasi Kerja, Disiplin Kerja Guru dan Kinerja Guru. Jurnal Pendidikan Penabur Vol 1, No. 04, 1-16.

Barnawi \& Arifin, Mohammad. (2012). Kinerja Guru Profesional. Jogjakarta: ArRuzz Media.

Choiriyah, dkk. (2017). Pengaruh Motivasi Kerja dan Iklim Sekolah Terhadap Komitmen Kerja Guru Sekolah Dasar Negeri Se-Kecamatan Semarang Timur, JMP: Jurnal Manajemen Pendidikan, Vol 6, No 2, 2017

Drucker, Peter F. (2007). Management Tasks, Responsibilities. New York: Harper \& Flow.

Inah, E.N. (2015). Peran Komunikasi Dalam Interaksi Guru dan Siswa, Jurnal Al-Ta'dib, Vol. 8 No. 2, JuliDesember 2015.

Hafid, M. (2017). Pengaruh Motivasi dan Kompetensi Guru Terhadap Kinerja Guru Sekolah dan Madrasah Di Lingkungan Pondok Pesantren 
Salafiyah Syafi'iyah Sukorejo, JPII, Vol 1, No 2, 2017.

Husna, N. (2017). Pengaruh Disiplin Kerja Terhadap Kinerja Guru Pada SMAN 1 Canduang Kabupaten Agam, Jurnal EKOBISTEK, Vol. 6, No. 2, Hal 286- 298, Oktober 2017,

Kusnadi, H. (2003). Masalah, Kerjasama, Konflik dan Kinerja (Kontemporer dan Islam). Malang: Taroda.

Mulyasa, E. (2009). Implementasi Kurikulum Tingkat Satuan Pendidikan Kemandirian Guru dan Kepala Sekolah. Jakarta: Bumi Aksara

Nugraheni, A.S \& Ratna Rahmayant. (2016). Pengaruh Disiplin Kerja Terhadap Kinerja Guru di MI Al Islam Tempel dan MI Al Ihsan Medari, Jurnal Pendidikan Madrasah, Volume 1, Nomor 2, November 2016

Riduwan. (2009). Metode dan Teknik Menyusun Tesis. Bandung: Alfabeta.

Ruliaty. (2009). Pengaruh Motivasi Kerja Terhadap Kinerja Guru di SMP Negeri 15 Kota Makassar. Balance: Jurnal Ilmu Ekonomi Studi Pembangunan, Vol 1, No. 1 Januari - April 2009.

Sedarmayanti. (2005). Sumberdaya Manusia dan Produktifitas Kerja. Bandung: Mandar Maju.

Arikunto, S. (2007). Manajemen Penelitian. Jakarta: Rineka Cipta 